\title{
ПЕРШОДЖЕРЕ ДА
}

\author{
Кароль Войтила
}

\section{ОСОБОВА СТРУКТУРА САМОВИЗНАЧЕННЯ*}

Моя доповідь має за мету не тільки дослідити певну проблему, що видається мені вкрай важливою для концепції людської особи та для творчого розвитку думки св. Томи в контексті різноманітних напрямів сучасного мислення (особливо феноменологіï). Я хотів би водночас поінформувати про стан цієї проблеми - як вона обговорюється в колах сучасних католицьких філософів Польщі. На початку цього виступу варто звернути увагу на дискусію, що розгорнулася після публікації моєї книги під назвою «Особа та вчинок» ${ }^{1}$. Дискусія розпочалася під час філософської конференції в Люблінському Католицькому університеті у грудні 1970 року. Опісля ця дискусія продовжилася вже у письмовій формі, у низці статей (біля 20), які опублікуються в «Analecta Cracoviensia» $^{2}$. В дискусії брали участь представники кількох наукових католицьких осередків, зокрема Любліна, Варшави й Кракова, які репрезентували різні філософські напрями. Під час обговорення особливу увагу було звернено на питання методології. Разом $з$ тим, не бракувало думок стосовно самої теорії особи, і навіть застосування цієї теорії в душпастирстві, педагогіці чи сучасній психіатрії. Дещо спрощуючи, можна сказати, що філософи Люблінської школи, між іншим, були зацікавлені методологічним уточненням думки св. Томи й спробою її пояснення сучасною мовою. Представники краківського осеред-

(C) I. Савинська, переклад, 2010

* Доповідь «Особова структура самовизначення» представлена 23 IV 1974 р. у Неаполі на Конгресі до 700-ліття смерті св. Томи, організованого 17-24 квітня 1974 р. в Римі-Неаполі заходами ордену домініканців; доповідь також виголошена 12 березня 1974 р. в рамках XVII Філософського тижня KUL (загальна тема тижня: «Актуальність томізму. До 700-ліття смерті св. Томи»).

Переклад здійснено Інною Савинською за Wojtyla Karol. Osoba i czyn oraz inne studia antropologiczne. - Lublin: KUL. - 2000. - s. 422-432.

${ }^{1}$ K. Wojtyla Osoba i czyn, Kraków, 1969 [wyd. II: Kraków, 1985; wyd. III: Lublin, 2000, s. 44-344 - peдакц. прим. до польського вид.].

2 «Analecta Cracoviensia», 1973. [Повна дискусія була опублікована в: «Analecta Cracoviensia», 5-6 (1973-1974), с. 49-272 - редакц. прим. до польського вид.]. 
ку, здебільшого, зацікавилися можливістю сучасного прочитання св. Томи в світлі певної версії феноменології. Книга «Особа та вчинок» викликала зацікавленість також і серед філософів-марксистів, які висловлювали поодинокі зауваги - хоча не брали безпосередньої участі у згаданій вище дискусії.

Нехай, ця передмова послугує вступом до питання особової структури самовизначення, яке перебуває в самому центрі моєї праці «Особа та вчинок». Розгортаючи його, я хотів би наголосити на зв'язку з рідним польським філософським осередком, з його сферою інтересів та творчими пошуками, що, зрештою, тяжіють до загальноєвропейських філософських течій.

Хоча польська наука й відносить себе до цих течій, однак, вона має власні неповторні риси, які пропонує широкому «ринку» інтелектуальної творчості (наприклад, коли йдеться про працю логіків Львівсько-Варшавської школи, про Р. Інгардена з Кракова). I завдяки цьому вона дедалі частіше займається щоденним формуванням польської інтелектуальної культури на власній Батьківщині.

Після вступної частини переходжу до викладу теми.

Щоб розкрити особову структуру самовизначення, варто пояснити широке значення досвіду людини. Безсумнівно, досвід людини не слід тлумачити у феноменалістичний спосіб, оскільки це закладає теорію пізнання, яка внутрішньо розподіляє пізнавальний процес між функціями чуттів і розуму, чуттєвими та поняттєвими змістами. Не заперечуючи різниці між цими функціями і їхніми змістами, варто зазначити, що людське пізнання становить органічну (не тільки організаційну) єдність. Першим і основним етапом людського пізнання завжди є досвід. Завдяки двоїстій структурі суб'єкту, він поєднує у собі чуттєве й розумове начало. Тому, можна визначити, що людський досвід - це вже певне розуміння, що розпочинає процес цілісного розуміння, яке хоча й формується у різноманітний спосіб, але завжди по відношенню до першого етапу, тобто до [розумового і чуттєвого начала - I. C.] досвіду. Таке пізнання забезпечує послідовний реалізм у філософії та науці, без якого створюваний образ світу ризикував би повністю втратити зв'язок $з$ дійсністю.

Те саме стосується і людини як предмету філософської антропології. Саме в конкретному й всебічному досвіді, вільному від будь-яких апріорних систем, ми маємо шукати підстав розуміння людини. Якщо аналізуємо особову структуру самовизначення, то розпочинаємо з досвіду людини, а особливо 3 людського вчинку. В ньому міститься суттєвий і важливий момент «пережиття» морального добра й зла, яке можна окреслити як досвід моральності. Однак, непотрібно цілковито розділяти досвід людини й моральний досвід. Хоча, у власному цілісному мисленнєвому процесі, людина може приділяти більше уваги одному 3 видів досвіду. В першому випадку, філософська рефлексія скеровуватиме до антропологіi, а в другому до етики. 
Досвід людського вчинку концентрується довкола пережиття факту «я дію». Він кожного разу єдиний, неповторний і цілковито оригінальний. Однак завжди зберігає тотожність як у пережитті однієї особи, так і в інтерсуб'єктивних вимірах. Досвід факту «я дію» вирізняється з-поміж досвідів усіх інших фактів, які тільки відбуваються, «діються», в особовому суб'єкті. Таке чітке розрізнення «діяння» в суб'єкті й «дії» суб'єкта або вчинку дозволяє нам схопити суттєвий аспект у цілісному досвіді людини,. Окреслимо його як самовизначення.

Первинна дефініція самовизначення у досвіді людського вчинку містить поняття принципу дієвості особового «Я»: «Я дію» - означає «Я дієва причина мого діяння», актуалізації суб'єкта. Це відрізняється від того що «в мені діється», оскільки тоді не йдеться про пережиття себе дієвою причиною. Розгляд принципу дієвості суб'єкта через дію відсилає до поняття «відповідальності» за здійснене, яка пронизує всі аксіологічні і етичні змісти вчинку. Сказане вище органічно вписується у досвід самовизначення, хоча розкривається у ньому різною мірою. Можна сказати, що це залежить від особової зрілості вчинку. Що вона повніша, то виразніше людина, діючий суб'єкт, переживає самовизначення. Що більше усвідомлюється дія і цінність, то виразніше людина (суб’єкт) переживає своє визначення. Що чіткіше вона переживає самовизначення, то ясніше в пережитті й свідомості вимальовується принцип дієвості й відповідальності.

Самовизначення як властивість людського вчинку, завдяки досвіду, звертає увагу дослідника на аспект волі як здатності особи. Воля - це здатність до самовизначення особи, яка виявляється при тісному пізнанні ії актів: простого акту волі «я прагну» й розвинутого процесу волі (вжито термінологію психологів Н. Аха, А. Мішота і кс. М. Дибовського з Польщі ${ }^{3}$ ). Простий акт волі у самовизначенні виражається в елементарному прагненні («я прагну»), виборі та прийнятті рішення, що $є$ результатом пізнання цінності, обдумування мотивів, а також, нерідко, їх змагань та битв усередині людини.

Якщо ми порівнясмо досягнення згаданих вище психологів волі з концепцією розвинутого й доконаного акту волі св. Томи, то знайдемо багато спільного. Одначе зараз не йдеться про порівняльний аналіз актів волі. Стверджуючи, що воля є здатністю до самовизначення особи, маємо на увазі волю не як методологічно ізольовану й обмежену щодо динаміки. Ми з необхідністю говоримо про всю особу. Самовизначення особи відбувається через акти волі (центральної здатності людської душі), але не зводиться до них. Самовизначення - це властивість самої особи. Наші роздуми весь час утримують-

3 Пор., наприклад, з М. Dybowski Zależność wykonania od cech procesu woli. - Warszawa. - 1926; його ж Działanie woli (Na tle badań eksperymentalnych). - Poznań. - 1946. 
ся у межах феноменологічного тлумачення досвіду. Зокрема, на цьому етапі пізнання, в світлі феноменології ясним стає розрізнення св. Томи між субстанцією і акциденцією, душею і їі здатністю: в цьому разі йдеться про волю. Здійснений (хоча й побіжно) аналіз дозволяє нам стверджувати, що самовизначення $є$ властивістю особи, про яку говорить відома дефініція: «rationalis naturae individua substantia» [«обдарована рацією природа індивідуальної субстанції» - визначення Боеція - I.C.]. Дана властивість втілюється через волю, яка становить здатність - акцидентальність. Проте, виявляючи суттєву свободу людини, самовизначення не обмежується тільки акцидентальним виміром. Воно також належить до субстанційного виміру особи: це свобода людини, а не тільки свобода волі в людині - хоча, безсумнівно, свобода людини через волю.

\section{III}

Стверджуючи, що дане в цілісному досвіді людини самовизначення спрямовує наш аналіз у бік акту волі, маємо запевнити, що такий аналіз недостатній, оскільки схоплює дійсність у феноменологічних категоріях інтенційного акту.

Розуміння волі лише як «прагнення», яке скеровує до відповідного предмету - цінності чи цілі - не розкриває її динаміки. Такий аналіз вказує тільки на один аспект волі й на один аспект властивої ій трансценденції. Акт волі це дієве скерування суб'єкта (наприклад, здатності в бік предмету чи цінності, які є ціллю і в такий спосіб становлять предмет прагнення). Також, дієве скерування (яке - NB - відрізняє акт волі від будь-яких «прагнень» чи «бажань», присутніх в суб'єкті) включає трансценденцію суб'єкта в бік цінності чи цілі; в деякій мірі, суб’єкт активно «виходить» за свої межі в напрямку цінності, при цьому залишаючись як і раніше тим самим «Я», яке й наважується на даний вихід. Можна таку трансценденцію визначити як горизонтальну. Видається, що аспекти інтенційності й «горизонтальної» трансценденції вичерпують аналіз волі в психології. Часто в тлумаченнях вчення св. Томи увага надто однобічно зосереджена довкола тематики волі.

Проте за допомогою цілісного досвіду людини та їі вчинку можемо повніше схопити динамізм волі. Звертаючи увагу на дійсність самовизначення, ми наближаємось до цілісної концепції, успадкованої від св. Томи. Самовизначення в акті волі не тільки виражає активне скерування суб'єкта до цінності. В ньому міститься щось більше, а саме: людина скеровується цим актом до наміченої цінності й не тільки визначає це скерування, а й через нього визначає саму себе. У понятті самовизначення присутнє більше, ніж в понятті принципу дієвості: людина не лише дієва причина для своїх вчинків, але й через них «творить саму себе». Діяння постає товаришем самовизначення, робить його органічнішим. Саме тому, самовизначення, а не тільки принцип дієвості особового «Я», тлумачить реальність і особовий характер мораль- 
них цінностей. Самовизначення пояснює, що людина стає «доброю» або «злою» завдяки вчинкам, а коли вже стала, то є «доброю» або «злою» людиною, як це грунтовно відзначив св. Тома ${ }^{4}$.

Якщо, аналізуючи волю як інтенційний акт, ми приймали б тільки горизонтальну трансценденцію, то неможливо було б пояснити реалізм і особовий характер моральних цінностей, добра і зла в людині.

Тому необхідно прийняти особову структуру самовизначення, яка виражається в окремих прагненнях і переростає чисту інтенційність тих прагнень (все одно, чи будуть ці прагнення прості чи теж складені завдяки волі). Інтенційність, певним чином, вказує на зовнішнє, на напрям до предмету, який є певною цінністю і через це притягує волю до себе. Натомість, самовизначення вказує на внутрішнє, на суб'єкт, який через прагнення окремої цінності, через іï вибір, визначає себе як цінність і стає «добрим» або «злим».

Людина визначає не тільки свої дії, але також і свою суть. Таким чином, самовизначенню відповідає стан окреслення людини як людини. (Завдяки ньому людина стає «кимось» в етично-особовому значенні, оскільки в онтичному значені $\epsilon$ «кимось» від самого початку. Додамо, що польський займенник «хтось» як протиставлення займеннику «щось» найлаконічніше схоплює особову виразність людини).

Виявляється, що досвід самовизначення - при своєму засадничо феноменологічному характері - впроваджує нас в щораз повніше розуміння дійсності, яку св. Тома визначив як actus humanus або як voluntarium.

Особова структура самовизначення виявляється одночасно умовою повного розуміння змісту феномену «Я дію». Якщо, слідом за Томою, приймаємо повну реальність моральних цінностей в предметі «людина», то разом 3 тим приймаємо, що особа як суб'єкт в акті самовизначення стає супроти себе як «предмет». Самовизначення виявляє внутрішню структуру особи; яка маючи онтичну єдність, кимось складена в своєму динамізмі; особа-суб'єкт весь час знаходиться у відношенні до особи-предмету. Самовизначення деякою мірою «упредметнює» діючий суб'єкт у його власній дії. Ця об’єктивізація особи не те саме, що іiі «реїфікація» [уречевлення, опредметнення - I.C.]; особа не може для себе стати річчю, хоча є невід'ємним «партнером» і в цьому сенсі, першим засадничим предметом, який вона визначає. Тобто, в цьому самовизначенні ㄲï суб'єктність актуалізується в найглибших потенціях, в суттєвих кваліфікаціях, які свідчать про людське (humanum) i разом $з$ тим особове.

${ }^{4}$ Пор. 3 (Summa theologiae, I-II, q. 56, а. 3), де св. Тома говорить про моральний принцип діяння, чи чесноти «ab huiusmodi habitibus simpliciter dicitur homo bonum operari et esse bonus». (Simpliciter означає «у власному значенні» і отже «як людина», і не тільки «на чийсь погляд»). Далі читаємо в тому ж місці: «non enim dicitur simpliciter aliquis homo bonus, ex hoc quod est sciens vel artifex: sed dicitur bonus solum secundum quid, puta bonus grammaticus, aut bonus faber». 
У процесі самовизначення людина-суб'єкт ставиться до себе як до предмета. Таке ставлення відкриває особливу складеність людини як особи. Св. Тома, а за ним і ціла традиція християнської думки, підкреслює, що «persona est sui iuris et alteri incommunicabilis» [особа належить самій собі й не передається іншому - I.C.]. Йдучи за томістичним дослідженням людини, ключовим моментом якого $є$ самовизначення, ми маємо переконатися у безпосередній очевидності традиційних дефініцій. Самовизначення особи виявляється як властива особі структура самоволодіння і самопанування. Тобто, людина спочатку визначає себе, і лише по тому, сама собою володіє i стає для себе паном. Ці реальності витлумачують одна одну, позаяк включають одна одну. Кожна з них становить складеність людини як особи. (NB. Томістичне adagium також підкреслює, що йдеться про особу: «persona est sui iuris et alteri incommunicabilis»). Мається на увазі не метафізична складеність людини 3 душі й тіла (= materia prima + forma substantialis), а радше складеність «феноменологічна». Феноменологічний досвід визначає людину як таку, що собою володіє, завдяки чому вона підвладна собі. Разом з тим, людина є сама собі паном і перебуває під власним пануванням. Перше й друге розуміється через самовизначення, становить його імплікацію і одночасно збагачує його зміст. Через самоволодіння і самопанування уповні оприявлюється особова структура самовизначення.

Здобуваючи самовизначення через акт волі, людина усвідомлює себе й одночасно з тим, свідчить іншим [людям - I.C.], що вона володіє собою і $\epsilon$ собі паном. Саме у такий спосіб учинки людини уможливлюють наше бачення певної особової структури. 3 методологічного боку ця структура представлена як сукупність необхідних умов, які уможливлюють опис того, що дане у досвіді. Завдяки самовизначенню, людина у безпосередній спосіб отримує досвід власного особового буття. Ясна річ, від досвіду до розуміння, яке становило б певну теорію особи, шлях пролягає через метафізичний аналіз. Такий аналіз дозволить нам, між іншим, осягнути особову структуру самовизначення в онтичній мінливості, обмеженості людського існування. Проте, досвід - необхідний початок цілого пізнавального шляху, центром якого $є$ пережиття самовизначення. В кожному разі, якщо повна афірмація особової цінності людських учинків вимагає певної теорії особи як свого підгрунтя, то іï побудова неможлива без аналізу динамічної дійсності вчинку й усього, що є суттєвим для нього в структурі самовизначення. Від початку ця структура до певної міри сприймається як особова структура.

У Пасторській конституції II Ватиканського собору Gaudium et spes [лат. «Радість та надія», 24, § 3 - I.C.] читаємо, що людина, це єдине створіння на землі, жадане Богом задля нього самого, може насправді цілковито віднайти 
себе тільки у щирому самодаруванні ${ }^{5}$. Цими словами документ останнього Собору коротко передає зміст багатовікової традиції і пошуків християнської антропології, для якої визвольним світлом стало Боже Об'явлення. Антропологія св. Томи з Аквіно глибоко закорінена в дусі цієї традиції. Вона відкрита для всіляких осягнень людської думки, які з різних боків доповнюють відпрацьовану в томістичній майстерні концепцію особи й підтверджують iї реалістичний характер. Цитата з II Собору, понад усім, акцентує увагу на аксіологічному аспекті та вказує на особу як особливу цінність саму по собі, що здатна дарувати себе. Через аксіологічний аспект легко буде відкрити онтологічний рівень. Онтологія особи, впроваджена через процитований текст, знову зустрічається 3 досвідом, який досліджуємо. Іншими словами: якщо ми прагнемо віднайти остаточну правду про людську особу, на якій наголошує Пастирська Конституція «Gaudium et spes», слід ще раз звернутися до особової структури самовизначення.

Як було зазначено, в досвіді самовизначення людська особа відкривається нам як незамкнена структура самоволодіння та самопанування. Ця структура означає особливий зв'язок з «самодаруванням», тобто 3 даром «не утилітарним». Річ в тім, що тільки той, хто сам собою володіє, може себе віддати - і зробити це без інтересу. I тільки той, хто для себе панує, може себе принести в дар - i знову без користі. Проблематика безкорисності заслуговує на спеціальний аналіз, який ми наразі оминаємо. Вчення II Ватиканського собору проголошує нове розуміння особи в категоріях дару, що сягає ще глибших вимірів, ніж ті, яких дістався сьогочасний аналіз. Видається, що можна ще більше дослідити особову структуру самовизначення.

Тільки той, хто «здатен визначати себе» - як ми це попередньо намагалися встановити - може також визначати себе як дар для інших. Складене твердження, що «людина [...] не може сповнитись у іншій повноті, крім неутилітарного самодарування», дозволяє нам дійти висновку, що коли людина стає даром для інших, вона здобуває себе. Таким чином, углиб динамічної структури особи вписане «право дару», якщо так можна сказати. Текст II Ватиканського собору повністю випливає 3 інтерпретації Об’явлення і в його світлі змальовує відповідний образ людини-особи. Можна висловити думку, що в цьому образі особа визначена як існування, бажане Богом «для неї самої» і, водночас, скероване «до» інших.

Одначе, цей реляційний образ особи зі всією необхідністю закладає іманентний (і побічно «субстанційний») образ, який відкривається нами завдяки аналізу особової структури самовизначення. Наприкінці обмежимось тільки зазначенням проблеми. Підбиваючи підсумки з теми особової структури са-

5 Душпастирська конституція про Церкву в сучасному світі «Gaudium et spes», 24, [в:] Konstytucje, dekrety, deklaracje: tekst łacińsko-polski / Sobór Watykański II, tekst łac.: Acta Apostolicae Sedis, tekst pol: tł. autoryzowane przez Konferencję Episkopatu Polski. - Paris : Éd. du Dialogue Société d'éditions Internationales, 1967. - 781, [2] s. 
мовизначення, слід додати, що, врешті-решт, це коротке дослідження оминуло цілу низку елементів, що заслуговують на ширше опрацювання (яке міститься у згаданому на початку дослідженні «Особа та вчинок»). Проте, навіть у цій невеликій доповіді ми намагались протиставити метафізичну концепцію особи, з якою ознайомились у св. Томи і в традиції томістичної філософії, сукупному досвіду людини. На шляху цього протиставлення ширше відкриваються пізнавальні джерела з яких Янгольський Доктор здобував своє метафізичне розуміння, висвітлюється велике багатство, заховане в тих джерелах і можливість черпання 3 них. А також краще розкривається можливість зустрічі й необхідність порозуміння з сучасною думкою в ім'я правди про дійсність. 